\title{
Implementasi Lembar Aktivitas Berbasis Pendekatan Saintifik untuk Meningkatkan Penalaran Spasial dan Self Esteem pada Mahasiswa Matematika
}

\author{
Westi Bilda , Dian Nopitasari , Desty Haswati
}

Universitas Muhammadiyah Tangerang, Indonesia

Correspondence: $\triangle$ westibilda@umt.ac.id

\begin{tabular}{|c|c|}
\hline Article Info & Abstract \\
\hline $\begin{array}{l}\text { Article History } \\
\text { Received : 03-10-2019 } \\
\text { Revised : 05-11-2019 } \\
\text { Accepted : 29-11-2019 }\end{array}$ & $\begin{array}{l}\text { Activity sheet is one of the tools that can be used in the learning activities } \\
\text { by applying the desired learning steps. The aim of this study is to find out } \\
\text { there is an increase in spatial reasoning and self esteem of students after } \\
\text { using a scientific-based activity sheet on Geometri Analitik Datar subiect. }\end{array}$ \\
\hline $\begin{array}{l}\text { Keywords: } \\
\text { self esteem; } \\
\text { spatial reasoning; } \\
\text { student activity sheets; }\end{array}$ & $\begin{array}{l}\text { This type of research is one-group pretest-posttets design conducted by } \\
\text { researchers before and after scientific-based activity sheets as treatment of } \\
\text { this research. The subjects of this study were the second semester students } \\
\text { who are learning Geometri Analitik Datar course consisted of } 30 \text { students. } \\
\text { The research instruments used ware spatial reasoning test in the form of } \\
\text { multiple choice tests and a self esteem questionnaire. The technical analysis } \\
\text { used were a descriptive analysis and N-Gain analysis. The result of the } \\
\text { research on spatial reasoning shows the pretest average score is } 58.83 \text { and } \\
\text { the posttest average score is } 76.17 \text {. It means that there is a significant } \\
\text { increasing result between pretest and posttest that is } 17.34 \text {. While the result } \\
\text { of self esteem shows the pretest average score is } 52.07 \text { and the posttest } \\
\text { average score is } 73.60 \text {. It means that there is a significant increasing result } \\
\text { in self esteem result that is } 21.53 \text {. The results of the spatial reasoning and } \\
\text { self esteem gain distribution range, both of them included medium criteria, } \\
\text { that is } 80 \% \text {. Thus it can be concluded that the spatial reasoning and self } \\
\text { esteem of students increases after applying learning using a scientific } \\
\text { approach based activity sheet. }\end{array}$ \\
\hline
\end{tabular}

\section{PENDAHULUAN}

Salah satu perangkat penting bagi keberhasilan pendidikan adalah kurikulum. Jika perangkat ini tidak tepat atau kurang sesuai maka akan sulit untuk mencapai tujuan dan sasaran pendidikan yang diinginkan. Di Indonesia, sudah beberapa kali diadakan perubahan dan perbaikan kurikulum. Perubahan ini didasari oleh kesadaran bahwa perkembangan dan perubahan yang terjadi dalam kehidupan bermasyarakat, berbangsa dan bernegara akibat pengaruh dari perubahan global, perkembangan ilmu pengetahuan, teknologi, serta seni dan budaya. Hal ini menuntut perlu adanya perbaikan sistem pendidikan nasional termasuk penyempurnaan kurikulum pendidikan sehingga masyarakat mampu bersaing dan menyesuaikan diri terhadap perubahan. Mulai dari perubahan kurikulum tahun 1947 yang masih dipengaruhi sistem pendidikan kolonial Belanda dan Jepang sampai pada saat ini berlaku kurikulum 2013.

Meskipun pemberlakuan kurikulum 2013 secara serentak mulai diberlakukan sejak tahun 2014, namun penerapan di lapangan masih banyak ditemui beberapa kendala terkait teknis dan perubahan paradigma. Beberapa kendala dalam perubahan paradigma tersebut yaitu siswa masih ingin diberi tahu 
daripada aktif mencari tahu; guru masih menjadi sumber belajar utama; pembelajaran belum maksimal menjadi keterampilan yang aplikatif; dan siswa belum terlatih dengan pembelajaran multi jawaban atau multi dimensi. Padahal pemerintah dalam hal ini Kemendikbud telah memberikan solusi melalui kurikulum ini yakni pembelajaran dengan pendekatan saintifik. Pendekatan ini diyakini dapat mengembangkan sikap, keterampilan dan pengetahuan mahasiswa karena di dalam proses kerjanya memenuhi kriteria ilmiah yakni lebih mengedepankan penalaran.

Pengembangan kemampuan berpikir matematis masih menjadi perhatian utama dalam pembelajaran matematika di Indonesia. Sebagai warga negara perlu memiliki kemampuan berpikir matematis sehingga mampu berpikir dan bersikap secara nalar dalam menyelesaikan permasalahan kehidupan sehari-hari melalui konsep matematis. Kemampuan ini pun perlu dikembangkan pada mahasiswa Pendidikan Matematika sebagai calon guru yang turut bertanggungjawab atas keberhasilan kualitas pembelajaran matematika di sekolah. Salah satu bidang kajian dalam pembelajaran matematika di sekolah maupun perguruan tinggi adalah geometri yang di dalamnya dibutuhkan kemampuan penalaran spasial.

Pengertian penalaran spasial menurut Sarma adalah proses di mana informasi suatu objek dalam ruang dan hubungan diantaranya dikumpulkan dengan berbagai cara, seperti pengukuran, pengamatan, atau kesimpulan, dan digunakan sampai pada kesimpulan yang valid mengenai hubungan objek-objek atau dalam menentukan bagaimana menyelesaikan tugas tertentu [1]. Kemampuan spasial dibagi menjadi tiga komponen diantaranya yaitu komponen untuk mengenali identitas sebuah objek yang ada di depannya dari sudut pandang yang berbeda dan kemampuan untuk membayangkan perubahan sebuah konfigurasi ketika komponen konfigurasi itu diubah atau dipindahkan [2]. Mahasiswa yang memiliki kemampuan penalaran spasialnya baik maka akan mampu membayangkan bagian-bagian suatu objek atau benda dari sisi atau sudut pandang yang berbeda .

Geometri Analitik Datar adalah salah satu mata kuliah wajib yang diberikan kepada mahasiswa program studi Pendidikan Matematika Universitas Muhammadiyah Tangerang. Mata kuliah ini merupakan mata kuliah prasyarat sebelum Geometri Analitik Ruang. Materi yang dibahas berkaitan dengan kemampuan membaca, mengamati serta menganalisis gambar, diagram, grafik, dan lain-lain. Oleh karena itu, mahasiswa perlu memiliki kemampuan penalaran spasial agar dapat membayangkan secara tepat dan akurat objek-objek dalam bidang atau ruang dan mampu memanipulasi di dalam pikirannya.

Untuk mendukung proses kegiatan pembelajaran agar kemampuan penalaran spasial mahasiswa dapat meningkat maka salah satunya dapat menggunakan perangkat bahan ajar berupa lembar aktivitas. Peneliti telah mendesain bahan ajar yang menyajikan materi ajar sekaligus lembar aktivitas dalam proses kegiatan pembelajaran dengan menerapkan langkah-langkah pembelajaran berbasis pendekatan saintifik. Pada pembelajaran matematika menurut Beckmann, langkah-langkah pendekatan saintifik terdiri dari pengumpulan data dari percobaan, pengembangan dan penyelidikan suatu model matematika ke dalam bentuk representasi yang berbeda, dan refleksi [3]. Pendekatan saintifik pada kurikulum 2013 menjabarkan langkah-langkah pembelajaran tersebut menjadi lima langkah, yaitu mengamati, menanya, menalar, mencoba dan mengkomunikasikan. Tentunya dalam mendesain lembar aktivitas ini, peneliti juga memperhatikan indikator apa saja yang ingin dicapai oleh mahasiswa sehingga hasil akhirnya akan sesuai dengan perencanaan yang telah dirancang terutama terhadap peningkatan kemampuan penalaran spasial mahasiswa.

Berdasarkan beberapa kajian tentang implementasi pendekatan saintifik terhadap kemampuan berpikir baik pemecahan masalah, berpikir HOTS maupun hasil belajar menunjukkan bahwa pembelajaran dengan pendekatan saintifik berpengaruh positif terhadap kemampuan tersebut [4] [5] [6]. Dalam kajiankajian tersebut terbatas pada kemampuan satu ranah kognitif saja sehingga peneliti bermaksud untuk mengimplementasikan pendekatan saintifik melalui penggunaan lembar aktivitas yang telah didesain pada dua kemampuan ranah kognitif dan afektif yakni kemampaun penalaran spasial dan self esteem mahasiswa. Penerapan lembar aktivitas berbasis saintifik ini diharapkan mampu meningkatkan kemampuan penalaran spasial sehingga mahasiswa mampu menilai kapasitas dirinya dengan mahasiswa lain dalam perolehan capaian akademik pada mata kuliah Geometri Analitik Datar. Kemampuan secara alami untuk menilai diri dan membandingkannya dengan orang lain ini dinamakan self esteem. Self esteem merupakan salah satu faktor utama dari bagaimana individu melihat dirinya atau konsep diri dan menjadi determinan penting dalam perilaku manusia [7].

Hasil penelitian yang dilakukan oleh Pamungkas dkk menunjukkan bahwa terdapat pengaruh yang signifikan antara pengetahuan awal dan self esteem terhadap kemampuan berpikir logis mahasiswa [8]. 
Tambunan juga menyatakan bahwa ada hubungan positif antara kemampuan spasial dengan prestasi belajar matematika baik kemampuan spasial total maupun kemampuan spasial euclidis [9]. Hal ini sejalan dengan hasil penelitian Wibowo yang menunjukkan bahwa terdapat korelasi yang signifikan antara self esteem dengan prestasi akademik [10]. Dalam penelitiannya dijelaskan bahwa hubungan antara seft esteem dengan prestasi akademik bersifat dua arah, bisa jadi self esteem mempengaruhi prestasi akademik, atau sebaliknya prestasi akademik mempengaruhi self esteem. Artinya mahasiswa bisa memiliki prestasi akademik tinggi akibat menilai dirinya positif, atau sebaliknya dikarenakan mendapat prestasi akademik yang baik sehingga membuat mahasiswa lebih menilai positif dalam menilai dirinya.

Kemampuan penalaran spasial menjadi bagian pendukung prestasi akademik pada mata kuliah Geometri Analitik Datar sehingga dapat diasumsikan bahwa terdapat pula korelasi antara self esteem dengan kemampuan penalaran spasial mahasiswa. Dengan harapan kemampuan penalaran spasial mahasiswa baik akibat menilai dirinya positif terhadap mata kuliah Geometri Analitik Datar (self esteem-nya baik). Atau sebaliknya dikarenakan kemampuan penalaran spasialnya baik sehingga membuat mahasiswa lebih positif dalam menilai dirinya (self esteem-nya baik).

Berdasarkan latar belakang di atas, maka penelitian ini bertujuan untuk mengetahui apakah terdapat peningkatan penalaran spasial dan self esteem mahasiswa setelah menggunakan lembar aktivitas berbasis saintifik pada mata kuliah Geometri Analitik Datar. Untuk menghindari salah penafsiran terhadap judul penelitian, berikut ini diberikan penjelasan berkenaan dengan istilah-istilah yang digunakan seperti: 1) implementasi yang dimaksud adalah penerapan atau penggunaan lembar aktivitas kepada mahasiswa yang mengontak mata kuliah Geometri Analitik Datar; 2) lembar aktivitas berbasis saintifik yang dibukukan dengan materi ajar; dan 3) saintifik adalah pendekatan ilmiah yang digunakan dalam pembelajaran sesuai dengan kurikulum 2013.

\section{METODE}

Penelitian ini dilaksanakan pada mahasiswa semester dua tahun akademik 2018/2019 Fakultas Keguruan dan Ilmu Pendidikan Universitas Muhammadiyah Tangerang yang menempuh mata kuliah Geometri Analitik Datar sebanyak 30 mahasiswa. Penelitian ini bertujuan untuk mengimplementasikan bahan ajar yang telah dikembangkan sebelumnya oleh peneliti yakni lembar aktivitas berbasis saintifik untuk meningkatkan kemampuan penalaran spasial dan self esteem mahasiswa. Jenis penelitian ini adalah one group pretest-postest yang dilakukan peneliti sebelum dan setelah memberikan perlakuan pembelajaran menggunakan lembar aktivitas berbasis saintifik. Instrumen penelitian yang digunakan adalah tes kemampuan penalaran spasial dan angket skala sikap self esteem yang telah divalidasi oleh validator ahli. Adapun self esteem yang diukur dalam penelitian ini adalah penilaian seseorang terhadap kemampuan (capability), keberhasilan (successfulness), kebermanfaatan (significance), dan kelayakan (wortbiness) dirinya dalam Geometri Analitik Datar. Teknik pengambilan data adalah tes kemampuan penalaran spasial dan angket skala self esteem yang dilakukan sebelum dan sesudah perlakuan. Adapun teknik analisis datanya menggunakan analisis statistik deskriptif dan analisis N-Gain.

$$
g=\frac{S_{\text {post }}-s_{\text {pre }}}{100-S_{\text {pre }}}
$$

Kriteria gain ternormalisasi $(\mathrm{g}): \mathrm{g}<0,3$ : rendah; $0,3 \leq \mathrm{g} \leq 0,7$ : sedang; $\mathrm{g}>0,7$ : tinggi.

\section{HASIL DAN PEMBAHASAN}

\section{Deskripsi Data}

Data hasil kemampuan penalaran spasial dan skala sikap self esteem dikumpulkan dan dianalisis untuk mengetahui kemampuan penalaran spasial dan skala sikap self esteem mahasiswa sebelum dan sesudah pemberian perlakuan. Berikut statistik deskriptif pencapaian penalaran spasial mahasiswa. 
Numerical: Jurnal Matematika dan Pendidikan Matematika, Vol. 3 No. 2 Desember 2019, 77-82

Westi Bilda , Dian Nopitasari , Desty Haswati

Tabel 1. Statistik Deskriptif Penalaran Spasial

\begin{tabular}{ccc}
\hline Statistik & \multicolumn{2}{c}{ Nilai Statistik } \\
\hline & Pretest & Posttest \\
Jumlah mahasiswa & 30 & 30 \\
\cline { 2 - 3 } Nilai tertinggi & 75 & 88 \\
Nilai terendah & 50 & 66 \\
Nilai rata-rata & 58,83 & 76,17 \\
Standar Deviasi & 5,04 & 6,28 \\
\hline
\end{tabular}

Berdasarkan tabel 1, terlihat bahwa pada nilai rata-rata pretest dan posttest terdapat perbedaan yakni nilai rata-rata pretest adalah sebesar 58,83 dan rata-rata posttest adalah 76,17 dengan selisih 17,34. Artinya kemampuan penalaran spasial mahasiswa setelah diberikan lembar aktivitas berbasis saintifik pada mata kuliah Geometri Analitik Datar lebih tinggi daripada sebelum diberikan lembar aktivitas berbasis saintifik. Selanjutnya dilakukan uji gain untuk melihat peningkatan kemampuan penalaran spasial mahasiswa dan kemudian diklasifikasikan ke kategori tinggi, sedang atau rendah. Berikut disajikan rangkuman distribusi dan persentase rata-rata $\mathrm{N}$-Gain berdasarkan kriteria indeks gain.

Tabel 2. Distribusi dan Persentase Perolehan Gain Penalaran Spasial

\begin{tabular}{ccccc}
\hline No & Rentang & Kategori & Frekuensi & Persentase (\%) \\
\hline 1 & $g>0,7$ & Tinggi & 1 & 3 \\
2 & $0,3 \leq g \leq 0,7$ & Sedang & 24 & 80 \\
3 & $g<0,3$ & Rendah & 5 & 17 \\
\hline & Jumlah & & 30 & 100 \\
\hline
\end{tabular}

Berdasarkan tabel 2, hasil uji gain penalaran spasial lebih dari 0,7 dengan kategori tinggi hanya satu mahasiswa, kategori sedang sebanyak 24 mahasiswa dan kategori rendah sebanyak lima mahasiswa. Sehingga dapat dilihat bahwa pada uji gain dengan rentang $0,3 \leq \mathrm{g} \leq 0,7$ atau kategori sedang memiliki persentase paling besar yaitu $80 \%$. Hal ini menunjukkan terjadinya peningkatan pada kemampuan penalaran spasial mahasiswa.

Selanjutnya, dilakukan pengolahan data hasil angket skala sikap self esteem. Berikut statistik deskriptif skala sikap self esteem mahasiswa.

Tabel 3. Statistik Deskriptif Skala Sikap Self Esteem

\begin{tabular}{ccc}
\hline Statistik & \multicolumn{2}{c}{ Nilai Statistik } \\
\hline & Pretest & Postest \\
\cline { 2 - 3 } Jumlah mahasiswa & 30 & 30 \\
Nilai tertinggi & 57 & 83 \\
Nilai terendah & 43 & 58 \\
Nilai rata-rata & 52,07 & 73,60 \\
Standar Deviasi & 4,70 & 7,76 \\
\hline
\end{tabular}

Berdasarkan tabel 3, nilai rata-rata pretest dan postest dari skala sikap self esteem mahasiswa juga terdapat perbedaan yakni nilai rata-rata pretest adalah sebesar 52,07 dan rata-rata posttest adalah 73,60 dengan selisih 21,53. Artinya self esteem mahasiswa setelah diberikan lembar aktivitas berbasis saintifik pada mata kuliah Geometri Analitik Datar lebih tinggi daripada sebelum diberikan lembar aktivitas berbasis saintifik. Selanjutnya dilakukan uji gain untuk melihat peningkatan skala sikap self esteem mahasiswa dan kemudian diklasifikasikan ke kategori tinggi, sedang atau rendah. Berikut disajikan rangkuman distribusi dan persentase rata-rata N-Gain berdasarkan kriteria indeks gain. 
Numerical: Jurnal Matematika dan Pendidikan Matematika, Vol. 3 No. 2 Desember 2019, 77-82

Westi Bilda , Dian Nopitasari , Desty Haswati

Tabel 4. Distribusi dan Persentase Perolehan Gain Self Esteem

\begin{tabular}{ccccc}
\hline No & Rentang & Kategori & Frekuensi & Persentase (\%) \\
\hline 1 & $\mathrm{~g}>0,7$ & Tinggi & 0 & 0 \\
2 & $0,3 \leq \mathrm{g} \leq 0,7$ & Sedang & 24 & 80 \\
3 & $\mathrm{~g}<0,3$ & Rendah & 6 & 20 \\
\hline & Jumlah & & 30 & 100 \\
\hline
\end{tabular}

Perolehan gain untuk skala sikap self esteem pada tabel 4, terlihat bahwa persentase paling besar berada pada kategori sedang sebesar $80 \%$ sedangkan kategori rendah hanya sebesar 20\%. Hal ini menunjukkan terjadinya peningkatan pada skala sikap self esteem mahasiswa setelah mendapatkan pembelajaran dengan menggunakan lembar aktivitas berbasis saintifik.

\section{Pembahasan}

Penelitian ini bertujuan untuk mengetahui apakah terdapat peningkatan penalaran spasial dan selfesteem mahasiswa setelah menggunakan lembar aktivitas berbasis saintifik pada mata kuliah Geometri Analitik Datar. Berdasarkan hasil analisis deskriptif data menunjukkan bahwa terdapat peningkatan dari pretest ke postest baik pada penalaran spasial maupun self esteem mahasiswa. Dengan kata lain penalaran spasial dan self esteem mahasiswa program studi Pendidikan Matematika semester dua yang menempuh mata kuliah Geometri Analitik Datar setelah diberi pembelajaran menggunakan lembar aktivitas berbasis pendekatan saintifik mengalami peningkatan yang signifikan pada kategori "sedang". Mahasiswa mampu menilai kapasitas dirinya dengan mahasiswa lain (self esteem) dalam perolehan capaian akademik pada mata kuliah Geometri Analitik Datar. Sebagaimana beberapa penelitian yang dilakukan oleh Erny dkk, Suhartati, dan Nuralam \& Eliyana menunjukkan bahwa pembelajaran dengan pendekatan saintifik berpengaruh positif terhadap kemampuan berpikir baik pemecahan masalah, berpikir HOTS maupun hasil belajar dan penelitian Wibowo yang menunjukkan bahwa terdapat korelasi yang signifikan antara self esteem dengan prestasi akademik[4] [5] [6] [10].

Pada lembar aktivitas yang diberikan mahasiswa terdapat langkah-langkah pembelajaran dengan pendekatan saintifik. Pertama, mahasiswa diminta untuk mengamati yaitu mengamati fakta matematika yang bukan hanya dari fenomena alam atau lingkungan atau objek konkrit melainkan juga dengan menerima kebenaran logis sehingga tidak mempermasalahkan suatu rangkaian sebelumnya yang didapatkan dari penalaran yang benar walaupun objeknya tidak nyata (abstrak). Pengamatan fakta matematika ini dapat berupa definisi, aksioma, postulat, teorema, sifat, grafik, dan lain sebagainya. Misalnya, mahasiswa diminta untuk menggambarkan persamaan lingkaran $(x-\alpha)^{2}+(y-\beta)^{2}=r^{2}$ dengan nilai $\alpha, \beta$ dan $r$ tertentu. Selanjutnya nilai $\alpha$ dan $\beta$ diubah dalam berbagai nilai sedangkan $r$ tetap. Maka akan terlihat bahwa $a$ dan $\beta$ mempengaruhi posisi titik pusat lingkaran yang terbentuk. Kedua, menanya yaitu kegiatan mahasiswa mengungkapkan apa yang ingin diketahuinya, baik yang berkenaan dengan suatu objek, peristiwa maupun proses tertentu. Untuk menggali pemikiran yang divergen agar mahasiswa tidak cenderung menghafal algoritma atau prosedur tertentu, dosen memberikan pertanyaan pancingan sehingga mahasiswa sendiri dapat menyelesaikan dan mencari alternatif lain. Misalkan dalam grafik persamaan lingkaran $(x-\alpha)^{2}+$ $(y-\beta)^{2}=r^{2}$, bagaimana jika salah satu dari nilai $\alpha$ atau $\beta$ negatif, keduanya negatif, keduanya nol, salah satunya nol dan sebagainya. Ketiga, mengumpulkan data yaitu kegiatan mahasiswa mencari informasi sebagai bahan untuk dianalisis dan disimpulkan yang tidak hanya dari fakta konkrit tetapi juga dari hasil pengumpulan kebenaran matematis. Keempat, mengasosiasi yaitu kegiatan mahasiswa mengolah data dalam bentuk serangkaian aktifitas fisik dan pikiran dengan bantuan peralatan tertentu sebagai akibat dari proses bernalar. Pada langkah ini mahasiswa dipandu untuk membayangkan bagian-bagian suatu objek atau benda dari sisi atau sudut pandang yang berbeda. Hal ini dapat membantu mahasiswa berpikir nalar terhadap konsep yang diberikan terutama penalaran spasial. Dan kelima, mengkomunikasikan yaitu kegiatan mahasiswa mendeskripsikan dan menyampaikan hasil temuannya dari kegiatan mengamati, menanya, mengumpulkan dan mengolah data, serta mengasosiasikan yang ditujukan kepada teman kelasnya baik secara lisan maupun tulisan.

Dengan demikian, penerapan lembar aktivitas berbasis saintifik ini mampu meningkatkan kemampuan penalaran spasial sehingga mahasiswa mampu menilai kapasitas dirinya (self esteem) dengan 
mahasiswa lain dalam perolehan capaian akademik pada mata kuliah Geometri Analitik Datar. Hal ini nampak pada diri mahasiswa yang menunjukkan rasa percaya diri terhadap kemampuannya dalam mata kuliah Geometri Analitik Datar, mampu memecahkan masalah matematis, mampu mengkomunikasi ide-ide matematisnya kepada dosen dan teman kelasnya, serta menyadari kekuatan dan kelemaan diriya dalam mata kuliah Geometri Analitik Datar. Oleh karena itu, $80 \%$ kemampuan penalaran spasial dan self esteem mahasiswa meningkat secara signifikan dan termasuk dalam kategori sedang.

Jika dilihat dari distribusi dan persentase rata-rata N-Gain berdasarkan kriteria indeks gain skala sikap selfesteem tak ada yang termasuk ke dalam kategori tinggi untuk peningkatan selfesteem (tabel 4). Artinya untuk mengubah sikap seseorang tidaklah mudah. Hal ini sesuai yang diungkapkan oleh Arikunto bahwa pengubahan sikap seseorang memerlukan waktu yang relatif lama karena pengukuran ranah afektif tidak dapat dilakukan setiap saat dan tingkah laku seseorang tidak dapat berubah sewaktu-waktu. Berbeda halnya dengan kemampuan kognitif dan psikomotor [11]. Namun, secara keseluruhan dalam hasil penelitian ini menunjukkan bahwa terdapat peningkatan penalaran spasial dan self esteem mahasiswa setelah menggunakan lembar aktivitas berbasis saintifik pada mata kuliah Geometri Analitik Datar [11].

\section{SIMPULAN DAN SARAN}

Berdasarkan hasil penelitian dan pembahasan di atas, maka dapat disimpulkan bahwa penalaran spasial dan self esteem mahasiswa meningkat setelah diterapkan pembelajaran menggunakan lembar aktifitas berbasis pendekatan saintifik pada mata kuliah Geometri Analitik Datar. Peningkatan terlihat setelah melakukan uji gain, dimana kedua varibel terikatnya mengalami peningkatan pada kategori sedang. Langkahlangkah pembelajaran saintifik pada lembar aktivitas membantu mahasiswa berpikir spasial sehingga mahasiswa mampu menilai kapasitas dirinya (self esteem) dengan mahasiswa lain dalam perolehan capaian akademik pada mata kuliah Geometri Analitik Datar. Pada penelitian ini, hanya dilakukan pada kelas kecil, sehingga saran untuk penelitian selanjutnya adalah melakukan penelitian dengan sampel yang lebih besar dan waktu yang relatif lama. Selain itu, dapat dilakukan pada variabel yang lain dengan penelitian ini untuk melihat hasil penelitian yang lebih bervariasi.

\section{DAFTAR PUSTAKA}

[1] F. R. Hidayat, Kresna Nur \& Fiantika, "Analisis Proses Berfikir Spasial Siswa Pada Materi Geometri Ditinjau Dari Gaya Belajar," dalam Analisis Proses Berpikir Spasial Siswa pada Materi Geometri Ditinjau dari Gaya Belajar, 2017.

[2] H. Gardner, Inteligencias múltiples. La teoría en la práctica. 1993.

[3] M. F. Atsnan dan R. Y. Gazali, "Penerapan Pendekatan Scientific Dalam Pembelajaran Matematika Smp Kelas Vii Materi Bilangan (Pecahan )," J. Pendidik., 2013.

[4] E. Erny, S. Haji, dan W. Widada, "Pengaruh Pendekatan Saintifik Pada Pembelajaran Matematika Terhadap Kemampuan Pemecahan Masalah Dan Kemampuan Berpikir Tingkat Tinggi Siswa Kelas X Ipa Sma Negeri 1 Kepahiang," J. Pendidik. Mat. Raflesia, vol. 2, no. 1, 2016.

[5] Suhartati, "Penerapan Pendekatan Saintifik Pada Materi Relasi Dan Fungsi Di Kelas X Man 3 Banda Aceh," J. Peluang, vol. 4, no. 2, 2016.

[6] N. Nuralam dan E. Eliyana, "Penerapan Pendekatan Saintifik Terhadap Kemampuan Pemecahan Masalah Matematika Di Sman 1 Darul Imarah Aceh Besar," J. Ilm. Didakt., vol. 18, no. 1, hlm. 64, 2018.

[7] E. Afari, G. Ward, dan M. S. Khine, "Global self-esteem and self-efficacy correlates: Relation of academic achievement and self-esteem among Emirati students," Int. Educ. Stud., 2012.

[8] A. S. Pamungkas, Y. Setiani, dan H. Pujiastuti, "Peranan Pengetahuan Awal dan Self Esteem Matematis Terhadap Kemampuan Berpikir Logis Mahasiswa," Kreano J. Mat. Kreat.-Inov., 2017.

[9] S. M. Tambunan, "Hubungan Antara Kemampuan Spasial Dengan Prestasi Belajar Matematika," Hub. Antara Kemamp. Spasial Dengan Prestasi Belajar Mat., vol. 10, no. 1, hlm. 27, 2006.

[10] S. B. Wibowo, "Benarkah Self Esteem Mempengaruhi Prestasi Akademik?," bumanitas, 2016.

[11] S. Sukanti, "Penilaian Afektif Dalam Pembelajaran Akuntansi," J. Pendidik. Akunt. Indones., 2011. 